\title{
Serum Adiponectin Level and Different Kinds of Cancer: A Review of Recent Evidence
}

\author{
Vajihe Izadi, ${ }^{1,2}$ Elaheh Farabad, ${ }^{1}$ and Leila Azadbakht ${ }^{1,2}$ \\ ${ }^{1}$ Food Security Research Center, Isfahan University of Medical Science, P.O. Box 81745, Isfahan, Iran \\ ${ }^{2}$ Departmant of Community Nutrition, School of Nutrition and Food Science, Isfahan University of Medical Science, \\ P.O. Box 81745, Isfahan, Iran
}

Correspondence should be addressed to Leila Azadbakht, azadbakht@hlth.mui.ac.ir

Received 30 July 2012; Accepted 24 September 2012

Academic Editors: N. Fujimoto, M. Loizidou, E. Sueoka, L.-M. Sun, and D. Tong

Copyright () 2012 Vajihe Izadi et al. This is an open access article distributed under the Creative Commons Attribution License, which permits unrestricted use, distribution, and reproduction in any medium, provided the original work is properly cited.

Background. Adiponectin, an adipokine secreted from adipose tissue, has antiobesity, anti-insulin resistance, and anticancer roles. The present study aimed to review the epidemiologic evidence about the association between adiponectin and cancers. Method. We searched in PubMed from 2002 to October 2011 by using the following key words: cancer, malignancy, cell proliferation, and adiponectin. Finally, 45 articles were recruited to review in the present paper. Findings. Several findings suggested inverse association between concentration of hormone and breast cancer risk. Low levels of adiponectin increase the risk of endometrial cancer in women. Adiponectin levels were significantly associated with prostate cancer in men. It seems that there is an inverse relationship between levels of adiponectin or its gene and colorectal cancer. Significant association between hormone and pancreatic cancer was found. Conclusion. Several findings suggested the negative correlation between adiponectin and risk of cancers. This relationship was more elucidated by the correlation between the hormone with obesity and insulin resistance. Suppression of growth and proliferation of cancer cells by adiponectin were explained via several mechanisms.

\section{Introduction}

Obesity, influenced by environmental and genetic factors, is one of the important factors in the etiology of metabolic syndrome, cardiovascular disease (CVD), and cancer [1-3]. Obesity is related to increased level of inflammatory markers such as CRP (C-reactive protein) that are associated with metabolic syndrome [4]. According to evidence of 2005, 937 and 396 million people around the world were obese and overweight, respectively [5]. Obesity is significantly correlated with an increase in dietary energy density and also it can elevate the risk of CVD and metabolic syndrome $[6,7]$. Adherence to the healthy dietary pattern $[8]$ and high intake of fruits and vegetables [9] are inversely related to metabolic syndrome. Moreover, the consumption of plant proteins, such as beans, drives a significant reduction in the inflammatory markers such as CRP, while meat consumption can increase inflammatory markers in bloodstream [10, 11]. Dietary intakes have major role in controlling the inflammation and also weight management [12]. Obesity increases the risk of cancer. A study showed that the risk of cancer in obese women is 50\% more than women with normal weight [13]. According to published studies, obesity, inflammation, insulin resistance, metabolic syndrome, cardiovascular disease, and cancer are significantly associated with concentrations of adiponectin [14-16].

Adiponectin is a peptide with 244 amino-acids, secreted from adipose tissue [17]. Plasma adiponectin levels in normal healthy individuals are $10 \mu \mathrm{g} / \mathrm{mL}$ where it accounts $0.01 \%$ of all plasma proteins [18]. This hormone presents in plasma as two important epimers: low molecular weight (LMW) or trimeric complex and high molecular weight (HMW) or oligomeric complex [15, 18]. Adiponectin inhibits vascular smooth muscle proliferation to prevent atherosclerosis. It also has an impact on pathogenesis of diabetes through the regulation of glucose and free fatty acid metabolisms and insulin sensitivity in the epithelial cells $[19,20]$. Two isoforms of adiponectin receptors were identified as Adipo $\mathrm{R}_{1}$ and Adipo $\mathrm{R}_{2}$. Adipo $\mathrm{R}_{1}$ receptors are predominantly expressed in muscle and Adipo $R_{2}$ receptors 
are mainly expressed in the liver [15]. Although the hormone is secreted from adipose tissue, as the weight increases the plasma level of adiponectin decreases. Moreover weight loss diets can elevate the level of adiponectin in plasma [21]. Higher adiponectin concentrations in women are more likely due to estrogen or androgen in their bloodstream and are independent of fat mass [22]. While testosterone in men causes a reduction in concentrations of serum adiponectin and prevents production of HMW in adipose tissue [23].

Several studies suggest that individuals with higher levels of adiponectin show generally higher concentrations of high density lipoprotein (HDL) and lower levels of low density lipoprotein (LDL), triglycerides (TG), and total cholesterol [24]. This hormone also plays an important role in the secretion of estrogen and insulin-like growth factor (IGF), which are important cancer risk factors [25]. Studies indicate that cancer cells express adiponectin receptors thus attaching adiponectin to its receptors may limit the proliferation of cancer cells $[18,26]$. Since obesity and insulin resistance are risk factors of cancer, adiponectin may act as an anticancer agent specially in breast cancer due to its significant effect on obesity and insulin resistance [15]. The relationship between adiponectin concentrations and prevention of cancer cells proliferation and its anticancer role $[1,27]$, and also the concentration of this hormone in patients with different types of cancers such as endometrial, breast, prostate, and colorectal cancer, has been investigated in several recent studies [2629] which indicates a close relationship between adiponectin and types of cancers. Most studies [1,27] but not all of them [29] suggest that the relationship between adiponectin and cancer is correlated with hormones, including estrogen, $\mathrm{IGF}_{1}$, obesity, and insulin resistance. Further investigations are needed to clarify the mechanisms of this relationship. This present study aims to review available evidence related to the serum adiponectin and breast, prostate, endometrial, and gastrointestinal tract cancers.

\section{Methods}

In order to examine the relationship between serum adiponectin levels and breast cancer, endometrial cancer, prostate cancer, and colorectal cancer, 153 articles between 2002 and October 2011 were accessed by using PubMed search engine and using keywords such as: cancer, malignancy, cell proliferation, and adiponectin.

45 articles with case control, cross-sectional, and prospective cohort design were reviewed. Other articles were excluded owing to lack of direct relation with the issue, duplication, and lack of access to full text articles. Studies that investigated among association between levels of adiponectin and cancer are shown in Table 1.

2.1. Relationship between Breast, Endometrial Cancers, and Concentrations of Adiponectin. Findings from several studies indicate an inverse relationship between serum adiponectin levels and breast cancer $[18,19,26]$. In a case control study on comprising 102 women with primary breast cancer patient and 100 healthy women, in the age of 5155 years, those in the lowest tertile of serum adiponectin levels $(\leq 9.6 \mu \mathrm{g} / \mathrm{mL})$ had a significantly higher risk of having breast cancer compared with women in the highest tertile $(\geq 10.6 \mu \mathrm{g} / \mathrm{mL})$ [20]. This relationship was observed in women both in pre- and postmenopause $(P<0.005)$. Another study showed, that risk of breast cancer in cases who were in the highest quartile of serum adiponectin levels were $77 \%$ less than those who were in the lowest quartile of hormone $(P=0.02)$. Patients with cancer had $6.21 \%$ and $3.12 \%$ lower levels of adiponectin and HMW, respectively [26]. There was no significant relationship between hormone levels and risk of breast cancer in pre- and postmenopausal women $\left(P_{\text {trend }}=0.09\right.$ and $P_{\text {trend }}=0.08$, resp.) [31]. In another case-control study on women with cancer and healthy women, aged 29-65 years, adiponectin levels in the cases were significantly $(P<0.005)$ lower than the controls. Also, obesity and physical inactivity can increase risk of breast cancer by 3 and 2-5 times, respectively. Low levels of adiponectin, obesity, and physical inactivity were reported as important risk factors for breast cancer in Malaysian women [19]. The presence of adiponectin in breast epithelial cells possibly has protective effects against cancer [32]. Study on 41 women with cancer and 45 control women suggested that serum adiponectin levels in the cases were nonsignificantly lower than control group $(P=0.37)$. Mean BMI in cases and controls was 23 [2]. $15.6 \%$ reduction in proliferation of MCF-7 breast cancer cells was reported by $10 \mu \mathrm{g} / \mathrm{mL}$ adiponectin levels, during the 96 hours, in comparison with controls [17]. To conclude, the findings of different studies suggest that risk of breast cancer in low adiponectin concentrations increases independent of BMI, leptin, IGF1, and menopausal status $[19,20]$.

According to a survey in 2004, higher BMI and lower serum adiponectin levels increased risk of endometrial cancer, 6.5 times, more than women with normal BMI and high adiponectin concentrations [33]. In this study, adiponectin was considered as a mediator to explain the relationship between insulin resistance, obesity, and endometrial cancer. In a prospective nested case-control study which was conducted on over 284 women with endometrial cancer and 548 healthy women, those who had the highest adiponectin levels were significantly at lower risk of endometrial cancer compared with the women with the lowest levels of hormone $\left(P_{\text {trend }}=0.006\right)$. This relationship was stronger in obese women [29]. Also women with the lowest concentrations of adiponectin were at risk of endometrial cancer 11 fold more than women who have the highest level of the hormone [34].

\subsection{Relationship between Serum Adiponectin and Prostate Cancer. The results of most epidemiological studies suggest an inverse relationship between hormone levels and risk of prostate cancer $[28,42]$. In a prospective study on 654 men with prostate cancer and 644 healthy men, the cases in the highest quintile of serum adiponectin had lower risk of fatal prostate cancer, compared with the lowest quintile of adiponectin concentration [43]. This relation- ship was not substantial after adjusting the effect of BMI}


TABLE 1: Studies that investigated among association between levels of adiponectin and cancer.

\begin{tabular}{|c|c|c|c|c|}
\hline Study & Type of study & Study comments & $(\mathrm{OR}, \mathrm{RR}, \mathrm{HR})^{1}$ & Adjusted variables \\
\hline Barb et al. [18] & Case-control & $\begin{array}{l}102 \text { women with } \\
\text { breast cancer } / 100 \\
\text { healthy women } \\
50-51 \text { years old }\end{array}$ & $\begin{array}{c}\text { OR } \\
3.62(1.61-8.19)\end{array}$ & $\begin{array}{l}\text { Age, family history, } \\
\text { menarche age, BMI, } \\
\text { menopause age, } \\
\text { marriage status }\end{array}$ \\
\hline
\end{tabular}

$\begin{array}{ccc} & & \\ \text { Jardé et al. [17] Case-control } \quad \begin{array}{l}70 \text { women with breast } \\ \text { cancer/28 healthy } \\ \text { women 25-65 years } \\ \text { old }\end{array} & 0.2(0.0-0.6\end{array}$

Employment status, age at first pregnancy, smoking, alcohol consumption, OCP, hormone therapy, family history, breastfeeding, BMI

Results

An inverse

relationship between adiponectin levels and breast cancer preand post menopause

Inverse relationship between hormone concentration and breast cancer in preand postmenopause/ abdominal obesity and physical inactivity increase the risk of cancer

Inverse relationship between adiponectin

174 women with

Cust et al. [29] Case-control breast cancer/167 healthy women
OR $0.84(0.71-0.99)$
IGF Components, leptin, BMI, and socioeconomic variables concentration and breast cancer in postmenopausal women

\begin{tabular}{ccl} 
Otake et al. [30] & Prospective & $\begin{array}{l}1477 \text { women with } \\
\text { breast cancer/2196 } \\
\text { case-control }\end{array}$ \\
& $\begin{array}{l}\text { healthy women } \\
30-55 \text { years old }\end{array}$ \\
\hline
\end{tabular}

$\begin{array}{cl}\text { RR } & \text { Age, menopausal } \\ 1.3(0.8-2.1)^{2} & \text { status, postmenopausal } \\ 0.73(0.55-0.98)^{3} & \text { hormone use }\end{array}$

No significant correlation between hormone levels and cancer risk

No significant correlation between hormone levels and risk of breast cancer in premenopause and a significant associated with breast cancer hormone in postmenopause 0.77 Reduction in the cancer risk in women who were at the highest quartile of adiponectin levels Stronger relationship between hormones and the risk of endometrial cancer in obese women

High energy intake and low adiponectin associated with increased risk of endometrial cancer

11-fold increased risk of endometrial cancer in people who were at the lowest level of adiponectin compared with the highest level 
TABle 1: Continued.

\begin{tabular}{|c|c|c|c|c|c|}
\hline Study & Type of study & Study comments & $(\mathrm{OR}, \mathrm{RR}, \mathrm{HR})^{1}$ & Adjusted variables & Results \\
\hline $\begin{array}{l}\text { Dal Maso et al. } \\
\text { [33] }\end{array}$ & Case control & $\begin{array}{l}84 \text { women with } \\
\text { endometrial } \\
\text { cancer } / 84 \text { healthy } \\
\text { women }\end{array}$ & $\begin{array}{c}\text { OR } \\
0.44(0.24-0.81)\end{array}$ & $\begin{array}{l}\text { IGF, leptin, BMI, } \\
\text { demographic-social } \\
\text { variables }\end{array}$ & $\begin{array}{l}1 \text { standard deviation } \\
\text { increased adiponectin } \\
\text { levels decreased } 50 \% \\
\text { risk of breast cancer } \\
\text { in women younger } \\
\text { than } 65 \text { years old. No } \\
\text { significant association } \\
\text { was found in } \\
\text { individuals older than } \\
65 \text { years }\end{array}$ \\
\hline $\begin{array}{l}\text { Soliman et al. } \\
\text { [34] }\end{array}$ & $\begin{array}{c}\text { Nested } \\
\text { case-control }\end{array}$ & $\begin{array}{l}698 \text { men with BPH/ } \\
705 \text { healthy men }\end{array}$ & $\begin{array}{c}\text { OR } \\
0.65(0.47-0.87)\end{array}$ & $\begin{array}{l}\text { BMI, alcohol } \\
\text { consumption, age }\end{array}$ & $\begin{array}{l}\text { People with the } \\
\text { highest hormone } \\
\text { concentration were in } \\
35 \% \text { lower risk for } \\
\text { BPH }\end{array}$ \\
\hline $\begin{array}{l}\text { Körner et al. } \\
{[26]}\end{array}$ & Case control & $\begin{array}{l}75 \text { men with prostatic } \\
\text { cancer/75 men with } \\
\text { BPH/150 healthy men }\end{array}$ & $\begin{array}{c}\text { OR } \\
0.9(0.1-0.82)\end{array}$ & $\begin{array}{l}\text { Age, BMI, alcohol } \\
\text { consumption, smoking }\end{array}$ & $\begin{array}{l}73 \% \text { lower risk of } \\
\text { prostate cancer in } \\
\text { those in the highest } \\
\text { quartile hormone } \\
\text { levels compared with } \\
\text { those who were in the } \\
\text { lowest quartile }\end{array}$ \\
\hline $\begin{array}{l}\text { Petridou et al. } \\
\text { [35] }\end{array}$ & Prospective & $\begin{array}{l}645 \text { men with } \\
\text { prostatic cancer and } \\
644 \text { healthy men }\end{array}$ & $\begin{array}{c}\text { HR } \\
0.35(0.14-0.86)\end{array}$ & $\begin{array}{l}\text { BMI, peptide C, type } \\
\text { and grade }\end{array}$ & $\begin{array}{l}\text { Inverse relationship } \\
\text { between sex } \\
\text { hormones and fatal } \\
\text { prostate cancer } \\
\text { (comparing quintile } 1 \\
\text { and 5) }\end{array}$ \\
\hline He et al. [36] & Case-control & $\begin{array}{l}30 \text { healthy people and } \\
62 \text { patients with } \\
\text { esophageal cancer }\end{array}$ & - & - & $\begin{array}{l}\text { Low adiponectin } \\
\text { levels in cancer } \\
\text { patients }(P<0.001)\end{array}$ \\
\hline $\begin{array}{l}\text { Beebe-Dimmer } \\
\text { et al. [37] }\end{array}$ & $\begin{array}{c}\text { Nested } \\
\text { case-control }\end{array}$ & $\begin{array}{l}381 \text { people with } \\
\text { colorectal cancer and } \\
381 \text { healthy people }\end{array}$ & - & - & $\begin{array}{l}\text { No significant } \\
\text { correlation between } \\
\text { serum adiponectin } \\
\text { levels and colorectal } \\
\text { cancer }\end{array}$ \\
\hline $\begin{array}{l}\text { Yildırım et al. } \\
\text { [38] }\end{array}$ & $\begin{array}{c}\text { Nested } \\
\text { case-control }\end{array}$ & $\begin{array}{l}311 \text { male cases with } \\
\text { pancreatic cancer, } \\
50-69 \text { years old } / 510 \\
\text { control subjects }\end{array}$ & $\begin{array}{c}\text { OR } \\
0.65(0.39-1.07)\end{array}$ & $\begin{array}{l}\text { Smoking status, blood } \\
\text { pressure, C-peptide }\end{array}$ & $\begin{array}{l}\text { The lower the cancer } \\
\text { risk in people who } \\
\text { were in the highest } \\
\text { quintile of serum } \\
\text { hormone }\end{array}$ \\
\hline $\begin{array}{l}\text { Goktas et al. } \\
{[39]}\end{array}$ & Prospective & $\begin{array}{l}18225 \text { men in total } \\
\text { that } 179 \text { of whom } \\
\text { were diagnosed with } \\
\text { colorectal cancer, } \\
\text { aged } 40-75 \text { years }\end{array}$ & $\begin{array}{c}\mathrm{RR} \\
0.48(0.25-0.9)\end{array}$ & BMI & $\begin{array}{l}\text { Significant correlation } \\
\text { between hormone } \\
\text { levels and cancer } \\
\text { risk-no significant } \\
\text { relationship was } \\
\text { observed after } \\
\text { adjustment for } \\
\text { potential } \\
\text { confounding }\end{array}$ \\
\hline $\begin{array}{l}\text { Kaklamani et al. } \\
{[40]}\end{array}$ & Case-control & $\begin{array}{l}420 \text { people with } \\
\text { colorectal cancer and } \\
555 \text { healthy people }\end{array}$ & $\begin{array}{c}\text { OR } \\
0.53(0.35-0.81)\end{array}$ & Age, sex & $\begin{array}{l}\text { Significant } \\
\text { relationship between } \\
\text { adiponectin } \mathrm{R}_{1} \\
\text { receptor and risk of } \\
\text { colorectal cancer }\end{array}$ \\
\hline
\end{tabular}


Table 1: Continued.

\begin{tabular}{|c|c|c|c|c|c|}
\hline Study & Type of study & Study comments & $(\mathrm{OR}, \mathrm{RR}, \mathrm{HR})^{1}$ & Adjusted variables & Results \\
\hline $\begin{array}{l}\text { Stolzenberg- } \\
\text { Solomon et al. } \\
{[41]}\end{array}$ & Case-control & $\begin{array}{l}81 \text { people with } \\
\text { pancreatic cancer and } \\
81 \text { healthy people }\end{array}$ & $\begin{array}{c}\text { OR } \\
2.81(1.04-7.59)\end{array}$ & $\begin{array}{l}\text { Age, sex, BMI, smoking } \\
\text { status, alcohol intake, } \\
\text { history of diabetes, } \\
\text { leptin }\end{array}$ & $\begin{array}{l}\text { Positive and } \\
\text { significant correlation } \\
\text { between hormone } \\
\text { concentrations and } \\
\text { risk of pancreatic } \\
\text { cancer }\end{array}$ \\
\hline
\end{tabular}

${ }^{1}$ RR: relative risk; OR: odds ratio; HR: hazard ratio.

${ }^{2} \mathrm{OR}$ in premenopausal women.

${ }^{3} \mathrm{RR}$ and $\mathrm{OR}$ in postmenopausal women.

${ }^{4} \mathrm{OR}$ results of low level of adiponectin in combination with $\geq 2500 \mathrm{kcal}$ energy intake.

and C-peptide. Based on this study, adiponectin is considered as a possible mediator between obesity and prostate cancer [43]. In another study on 25 patients with benign prostatic hyperplasia and 43 prostate cancer patients, there was not any significant difference between hormone levels in both groups [44]. HMW may be considered as a growth inhibitor for proliferation and prostate cancer cells [45]. Also in a study, serum adiponectin was called as a potential antiprostate cancer [46]. In another case-control study, adiponectin concentrations in patients with prostate cancer were less than controls [39]. Different types of adiponectin gene in African American men with prostate cancer, who participated in a community-based case-control study, did not show significant association with prostate cancer [37].

\subsection{Relationship between Adiponectin Levels and Gastroin-} testinal Tract Cancer. It seems that there is an inverse relationship between serum adiponectin concentrations, colon, and colorectal cancer $[30,47,48]$. In a cohort study, low levels of adiponectin were considered as a more important risk factor than BMI and TG in early stage of colorectal cancer [30]. This hormone was not a significant risk factor for advanced colorectal cancer. The risk of colorectal cancer in men who had high plasma adiponectin concentrations was $60 \%$ lower than those with lower levels of adiponectin after adjusting for some potential confounding (BMI, waist circumference, and physical activity) [47]. In a nested prospective case-control study on 381 men with colorectal cancer and 381 healthy men, no significant association between hormone levels and colorectal cancer was found [48]. On the other hand, in another study on men and women aged 48-80 with colon cancer, with and without cachexia, a higher level of adiponectin was observed in those with 5\% or more BMI reduction in 6 months [49]. In this study no correlation was observed between weight loss and adiponectin levels. Results from several case-control colorectal cancer studies represent important role of a variety of adiponectin gene (ADIPOQ) at increasing the risk of colorectal cancer [50] or reduce its risk [40]. Results of a meta-analysis did not show any relationship between ADIPOQ change and colorectal cancer [51]. In another case-control study on 420 cancer patients with colorectal cancer and 555 control subjects, matched by age and sex factors, substantial association was found between Adipo $\mathrm{R}_{1}$ receptor and risk of colorectal cancer [36]. In a study on
62 cancer patients and 30 healthy individuals, in the age of 20-83 years, adiponectin levels were significantly lower $(P<0.001)$ in patients with oesophageal cancer [38]. This inverse relationship was significant in those blood samples that are collected over 5 years $\left(P_{\text {trend }}=0.031\right)$ [38]. While the results of two small case-control studies on pancreatic cancer, a conflicting correlation show between adiponectin levels and pancreatic cancer both in men and women $[52,53]$.

\section{Discussion}

The evidence from studies suggests a significant inverse relationship between serum adiponectin levels and risk of prostate, breast, endometrial, and colorectal cancer. Hormone levels are usually reduced in cancer patients $[1,30,33$, 43].

Adiponectin is inversely associated with obesity and insulin resistance and also it stimulates insulin sensitivity of peripheral tissues [1]. On the other hand, adiponectin reduction is associated with insulin resistance which leads to an increase in the levels and activity of $\mathrm{IGF}_{1}$. High concentrations of circulating $\mathrm{IGF}_{1}$ can increase the risk of breast cancer $[2,27]$. Inverse relationship between adiponectin and breast cancer in post-menopausal women confirms the main effect of adiponectin in the pathogenesis of insulin resistancerelated cancers such as breast cancer caused by obesity [27, 54]. IGF $_{1}$ and insulin are effective in carcinogenesis through binding to their receptors which leads to an increase in cell proliferation and inhibit apoptosis in tissues which regulate the secretion of vascular endothelial growth factor (VEFG) [15]. VEGF is secreted by breast cancer cells [55]. This factor is restrained by increasing the level of adiponectin through stimulating the ligand of peroxisome proliferator activated receptor $\gamma(\operatorname{PPAR} \gamma)$ [56]. Thus low levels of adiponectin leads to reduction in PPAR $y$ activity [57] and thus increase the risk of cancer. According to a study, the relationship between adiponectin and breast cancer risk is independent of the possible effects of IGF major system components, leptin, BMI, and menopausal status [18, 27].

Adiponectin plays an effective role in glucose metabolism, so that augmentation of glucose level lead to reduction of adiponectin. Importance of adiponectin on glucose and lipid metabolism is through the adiponectin receptors $\left(\mathrm{R}_{1}\right.$ and $\mathrm{R}_{2}$ ) [58]. Relationship between obesity and breast cancer is mainly due to the estrogen receptors $[2,59])$. Adiponectin 
suppresses the stimulation of growing cancer cells caused by estradiol [60]. Low level of adiponectin in obese patients and high level of estrogen increase the risk of breast cancer. While in another study the inverse relationship between hormone levels and breast cancer risk has been considered independent of estrogen levels during menopause [31]. In a case-control study on 70 women with cancer, low levels of adiponectin associated with obesity and lack of physical activity throughout life was considered as important risk factors for breast cancer as physical activity can decrease the cancer risk by $2-5$ times. Physical activity can delay the first menstrual cycle by affecting a secretory production of ovarian hormones that reduce the risk of breast cancer [19].

Overweight and reduction of adiponectin concentrations are associated with endometrial cancer substantially by increasing estrogen and insulin resistance [33]. These hormones and obesity may each independently be associated with endometrial cancer [29]. Adiponectin increased adenosine monophosphate kinase (AMPK) and PPAR. AMPK and PPAR pathway activation leads to increasing insulin sensitivity and free fatty acid oxidation [61]. On the other hand, AMPK has direct effects on insulin resistance, cell proliferation, and apoptosis and it can interfere in tumor growth [29]. Thus reduction of AMPK can be effective in endometrial cancer. Adipo $\mathrm{R}_{1}$ receptors act mainly through AMPK pathways. Inhibitory effects of adiponectin on cancer cells are mainly affected by AMPK activity. Adipo $\mathrm{R}_{1}$ receptor plays an anticarcinogenic role [62].

A research found that HMW has an inhibitory activity on prostate cancer cell growth and proliferation [45]. Furthermore, another study indicates a reduction of expression of adipo $R_{1}$ and $R_{2}$ receptors in prostate cancer tissues compared to benign prostatic hyperplasia ( $\mathrm{BPH})$ and healthy tissue [28]. Natural concentrations of adiponectin inhibit cancer cell growth, metastasis, and cancer cell lines and also inhibit dehydrotestosterone that stimulates cell proliferation $[42,62]$. Adiponectin reduces the growth of androgen of prostate cancer cells through activation of AMPK up to 90\% [63]. The hormone inhibits inflammation by inhibiting the activity of mature phagocytic macrophages which are associated with prostate cancer [64]. Obesity increases insulin production and insulin resistance. In addition, it can reduce adiponectin levels and AMPK activity which increase the risk of prostate cancer $[28,43]$.

$\mathrm{IGF}_{1}$ inhibits apoptosis and increases production of VEGF [41]. This factor is increased in patients with oesophageal cancer. Adiponectin has an inhibitory effect on transcription factor which is involved in regulation of VEGF [27]. This hormone also increased AMP kinase and also inhibits proliferation of colonic epithelial cells [65]. The reduction of the IGF binding protein $\left(\mathrm{IGF}_{1} \mathrm{BP}\right)$ and increasing $\mathrm{IGF}_{1}$ in low levels of adiponectin concentrations can increase cell proliferation and inhibits apoptosis in colorectal cancer cells [47]. $\mathrm{R}_{1}$ and $\mathrm{R}_{2}$ adiponectin receptor expression in pancreatic $\beta$-cells expresses the relationship of adiponectin with the endocrine activity of pancreas [66]. This hormone can directly inhibit the growth and proliferation of pancreatic cancer cells [41]. On the other hand, positive correlation between adiponectin concentrations and risk of pancreatic cancer in two case-control studies with small sample volumes was found $[52,53]$. Furthermore, the elevation of hormone secretion in cancer cells may be due to reducing hormone receptors [52]. However, in a study on 81 patients with pancreatic cancer and 81 healthy men and women $R_{1}$ and $R_{2}$ receptors on cancer cells were significantly expressed [52].

Adiponectin receptor agonist that is called 355ADP was identified by isolating 149-166 peptide of adiponectin sequence. 355ADP adiponectin with similar behaviour to adiponectin was discussed as a recommended way to treat obesity, insulin resistance, and cancer [14].

Adherence to Mediterranean dietary pattern and healthy dietary pattern can increase circulating adiponectin levels [67-69]. This association is shown not only in cohort and cross-sectional studies [68-70], but also in clinical trials [71]. Consumption of diet rich in fiber, low fat dairy products, whole grain, reducing energy intake from saturated fatty acids and refined grain, and increased consumption of fish and fish products and vegetable proteins may be effective to improve adiponectin levels $[67,68]$. Low calorie diet with $10 \%$ weight reduction, in overweight and obese individuals, can influence on improvement of hormone levels $[21,72,73]$. As the importance of dietary pattern and dietary components on circulating adiponectin level, more investigations are recommended to clarify the effect of diet on adiponectin level.

\section{Conclusion}

This study aimed to review the results of studies on the relationship between serum adiponectin levels and risk of cancer. Findings from different studies represent an inverse relationship between hormone levels and the risk of breast cancer $[1,27,31]$, independent of BMI and menopausal status [20]. This association was observed in prospective and case-control studies [27, 31], both in pre- and postmenopausal women [20]. The risk of endometrial cancer in women who had high circulating adiponectin levels was less than those with lower adiponectin levels [34]. Also, it seems that the risk of prostate cancer and benign prostatic hyperplasia in men with low adiponectin level is higher than others $[44,46]$. Several cohort and case-control studies suggest an inverse relationship between serum levels of adiponectin, genomic changes, and colorectal cancer risk $[36,48]$. Result of a study on esophageal cancer indicates a low level of hormones in the patients [38]. It seems that there is an inverse relationship between plasma adiponectin and pancreatic cancer in men [41]. However, the results are conflicting in the men and women $[52,53]$.

\section{References}

[1] Y. F. Tian, C. H. Chu, M. H. Wu et al., "Anthropometric measures, plasma adiponectin, and breast cancer risk," EndocrineRelated Cancer, vol. 14, no. 3, pp. 669-677, 2007.

[2] J. H. Kang, B. Y. Yu, and D. S. Youn, "Relationship of serum adiponectin and resistin levels with breast cancer risk," Journal of Korean Medical Science, vol. 22, no. 1, pp. 117-121, 2007. 
[3] A. Esmaillzadeh and L. Azadbakht, "Major dietary patterns in relation to general obesity and central adiposity among Iranian women," Journal of Nutrition, vol. 138, no. 2, pp. 358363, 2008.

[4] K. F. Hilpert, P. M. Kris-Etherton, and S. G. West, "Lipid response to a low-fat diet with or without soy is modified by C-reactive protein status in moderately hypercholesterolemic adults," Journal of Nutrition, vol. 135, no. 5, pp. 1075-1079, 2005.

[5] F. Hosseinpanah, M. Barzin, P. S. Eskandary, P. Mirmiran, and F. Azizi, "Trends of obesity and abdominal obesity in Tehranian adults: a cohort study," BMC Public Health, vol. 9, article 426, 2009.

[6] A. Esmaillzadeh, H. Khosravi Boroujeni, and L. Azadbakht, "Consumption of energy-dense diets in relation to cardiometabolic abnormalities among Iranian women," Public Health Nutrition, vol. 19, pp. 1-8, 2011.

[7] A. Esmaillzadeh and L. Azadbakht, "Dietary energy density and the metabolic syndrome among Iranian women," European Journal of Clinical Nutrition, vol. 65, no. 5, pp. 598-605, 2011.

[8] A. Esmaillzadeh, M. Kimiagar, Y. Mehrabi, L. Azadbakht, F. B. $\mathrm{Hu}$, and $\mathrm{W}$. C. Willett, "Dietary patterns, insulin resistance, and prevalence of the metabolic syndrome in women," American Journal of Clinical Nutrition, vol. 85, no. 3, pp. 910-918, 2007.

[9] A. Esmaillzadeh, M. Kimiagar, Y. Mehrabi, L. Azadbakht, F. B. $\mathrm{Hu}$, and W. C. Willett, "Fruit and vegetable intakes, C-reactive protein, and the metabolic syndrome," American Journal of Clinical Nutrition, vol. 84, no. 6, pp. 1489-1497, 2006.

[10] A. Esmaillzadeh and L. Azadbakht, "Legume consumption is inversely associated with serum concentrations of adhesion molecules and inflammatory biomarkers among Iranian women," Journal of Nutrition, vol. 142, pp. 334-339, 2012.

[11] L. Azadbakht and A. Esmaillzadeh, "Red meat intake is associated with metabolic syndrome and the plasma c-reactive protein concentration in women," Journal of Nutrition, vol. 139, no. 2, pp. 335-339, 2009.

[12] L. Azadbakht, P. J. Surkan, A. Esmaillzadeh, and W. C. Willett, "The dietary approaches to stop hypertension eating plan affects $\mathrm{C}$-reactive protein, coagulation abnormalities, and hepatic function tests among type 2 diabetic patients," Journal of Nutrition, vol. 141, no. 6, pp. 1083-1088, 2011.

[13] E. E. Calle and R. Kaaks, "Overweight, obesity and cancer: epidemiological evidence and proposed mechanisms," Nature Reviews Cancer, vol. 4, no. 8, pp. 579-591, 2004.

[14] L. Otvos Jr., E. Haspinger, F. L. Russa et al., "Design and development of a peptide-based adiponectin receptor agonist for cancer treatment," BMC Biotechnology, vol. 11, article 90, 2011.

[15] I. Kelesidis, T. Kelesidis, and C. S. Mantzoros, "Adiponectin and cancer: a systematic review," British Journal of Cancer, vol. 94, no. 9, pp. 1221-1225, 2006.

[16] M. E. Grossmann, K. J. Nkhata, N. K. Mizuno, A. Ray, and M. P. Cleary, "Effects of adiponectin on breast cancer cell growth and signaling," British Journal of Cancer, vol. 98, no. 2, pp. 370-379, 2008.

[17] T. Jardé, F. Caldefie-Chézet, N. Goncalves-Mendes et al., "Involvement of adiponectin and leptin in breast cancer: clinical and in vitro studies," Endocrine-Related Cancer, vol. 16, no. 4, pp. 1197-1210, 2009.

[18] D. Barb, C. J. Williams, A. K. Neuwirth, and C. S. Mantzoros, "Adiponectin in relation to malignancies: a review of existing basic research and clinical evidence," American Journal of Clinical Nutrition, vol. 86, no. 3, pp. S858-S866, 2007.

[19] S. Shahar, R. M. Salleh, A. R. Ghazali, P. B. Koon, and W. N. Wan Mohamud, "Roles of adiposity, lifetime physical activity and serum adiponectin in occurrence of breast cancer among Malaysian women in Klang Valley," Asian Pacific Journal of Cancer Prevention, vol. 11, no. 1, pp. 61-66, 2010.

[20] Y. Miyoshi, T. Funahashi, S. Kihara et al., "Association of serum adiponectin levels with breast cancer risk," Clinical Cancer Research, vol. 9, no. 15, pp. 5699-5704, 2003.

[21] Y. M. Liu, J. M. Lacorte, N. Viguerie et al., "Adiponectin gene expression in subcutaneous adipose tissue of obese women in response to short-term very low calorie diet and refeeding," Journal of Clinical Endocrinology and Metabolism, vol. 88, no. 12, pp. 5881-5886, 2003.

[22] M. Cnop, P. J. Havel, K. M. Utzschneider et al., "Relationship of adiponectin to body fat distribution, insulin sensitivity and plasma lipoproteins: evidence for independent roles of age and sex," Diabetologia, vol. 46, no. 4, pp. 459-469, 2003.

[23] A. Xu, K. W. Chan, R. L. C. Hoo et al., "Testosterone selectively reduces the high molecular weight form of adiponectin by inhibiting its secretion from adipocytes," Journal of Biological Chemistry, vol. 280, no. 18, pp. 18073-18080, 2005.

[24] N. Bansal, V. Charlton-Menys, P. Pemberton et al., "Adiponectin in umbilical cord blood is inversely related to low-density lipoprotein cholesterol but not ethnicity," Journal of Clinical Endocrinology and Metabolism, vol. 91, no. 6, pp. 2244-2249, 2006.

[25] V. G. Kaklamani, M. Sadim, A. Hsi et al., "Variants of the adiponectin and adiponectin receptor 1 genes and breast cancer risk," Cancer Research, vol. 68, no. 9, pp. 3178-3184, 2008.

[26] A. Körner, K. Pazaitou-Panayiotou, T. Kelesidis et al., “Total and high-molecular-weight adiponectin in breast cancer: in vitro and in vivo studies," Journal of Clinical Endocrinology and Metabolism, vol. 92, no. 3, pp. 1041-1048, 2007.

[27] C. Mantzoros, E. Petridou, N. Dessypris et al., "Adiponectin and breast cancer risk," Journal of Clinical Endocrinology and Metabolism, vol. 89, no. 3, pp. 1102-1107, 2004.

[28] K. Michalakis, C. J. Williams, N. Mitsiades et al., "Serum adiponectin concentrations and tissue expression of adiponectin receptors are reduced in patients with prostate cancer: a case control study," Cancer Epidemiology Biomarkers and Prevention, vol. 16, no. 2, pp. 308-313, 2007.

[29] A. E. Cust, R. Kaaks, C. Friedenreich et al., "Plasma adiponectin levels and endometrial cancer risk in pre- and postmenopausal women," Journal of Clinical Endocrinology and Metabolism, vol. 92, no. 1, pp. 255-263, 2007.

[30] S. Otake, H. Takeda, S. Fujishima et al., "Decreased levels of plasma adiponectin associated with increased risk of colorectal cancer," World Journal of Gastroenterology, vol. 16, no. 10, pp. 1252-1257, 2010.

[31] S. S. Tworoger, A. H. Eliassen, T. Kelesidis et al., "Plasma adiponectin concentrations and risk of incident breast cancer," Journal of Clinical Endocrinology and Metabolism, vol. 92, no. 4, pp. 1510-1516, 2007.

[32] O. Treeck, C. Lattrich, I. Juhasz-Boess, S. Buchholz, G. Pfeiler, and O. Ortmann, "Adiponectin differentially affects gene expression in human mammary epithelial and breast cancer cells," British Journal of Cancer, vol. 99, no. 8, pp. 1246-1250, 2008.

[33] L. Dal Maso, L. S. A. Augustin, A. Karalis et al., "Circulating adiponectin and endometrial cancer risk," Journal of Clinical 
Endocrinology and Metabolism, vol. 89, no. 3, pp. 1160-1163, 2004.

[34] P. T. Soliman, D. Wu, G. Tortolero-Luna et al., "Association between adiponectin, insulin resistance, and endometrial cancer," Cancer, vol. 106, no. 11, pp. 2376-2381, 2006.

[35] E. Petridou, C. Mantzoros, N. Dessypris et al., "Clinical case seminar - Plasma adiponectin concentrations in relation to endometrial cancer: a case-control study in Greece," Journal of Clinical Endocrinology and Metabolism, vol. 88, no. 3, pp. 993-997, 2003.

[36] B. He, Y. Pan, Y. Zhang et al., "Effects of genetic variations in the Adiponectin pathway genes on the risk of colorectal cancer in the Chinese population," BMC Medical Genetics, vol. 12, article 94, 2011.

[37] J. L. Beebe-Dimmer, K. A. Zuhlke, A. M. Ray, E. M. Lange, and K. A. Cooney, "Genetic variation in adiponectin (ADIPOQ) and the type 1 receptor (ADIPOR1), obesity and prostate cancer in African Americans," Prostate Cancer and Prostatic Diseases, vol. 13, no. 4, pp. 362-368, 2010.

[38] A. Yıldırım, M. Bilici, K. Çayir, V. Yanmaz, S. Yildirim, and S. B. Tekin, "Serum adiponectin levels in patients with esophageal cancer," Japanese Journal of Clinical Oncology, vol. 39, no. 2, pp. 92-96, 2009.

[39] S. Goktas, M. I. Yilmaz, K. Caglar, A. Sonmez, S. Kilic, and S. Bedir, "Prostate cancer and adiponectin," Urology, vol. 65, no. 6, pp. 1168-1172, 2005.

[40] V. G. Kaklamani, K. B. Wisinski, M. Sadim et al., "Variants of the adiponectin (ADIPOQ) and adiponectin receptor 1 (ADIPOR1) genes and colorectal cancer risk," Journal of the American Medical Association, vol. 300, no. 13, pp. 1523-1531, 2008.

[41] R. Z. Stolzenberg-Solomon, S. Weinstein, M. Pollak et al., "Prediagnostic adiponectin concentrations and pancreatic cancer risk in male smokers," American Journal of Epidemiology, vol. 168, no. 9, pp. 1047-1055, 2008.

[42] J. M. Schenk, A. R. Kristal, M. L. Neuhouser et al., "Serum adiponectin, C-peptide and leptin and risk of symptomatic benign prostatic hyperplasia: results from the prostate cancer prevention trial," Prostate, vol. 69, no. 12, pp. 1303-1311, 2009.

[43] H. Li, M. J. Stampfer, L. Mucci et al., “A 25-year prospective study of plasma adiponectin and leptin concentrations and prostate cancer risk and survival," Clinical Chemistry, vol. 56, no. 1, pp. 34-43, 2010.

[44] D. Housa, Z. Vernerova, J. Heracek et al., "Adiponectin as a potential marker of prostate cancer progression: studies in organ-confined and locally advanced prostate cancer," Physiological Research, vol. 57, pp. 451-458, 2008.

[45] J. D. Bub, T. Miyazaki, and Y. Iwamoto, "Adiponectin as a growth inhibitor in prostate cancer cells," Biochemical and Biophysical Research Communications, vol. 340, no. 4, pp. 1158-1166, 2006.

[46] C. M. L. Fontana, M. E. M. Artola, N. D. M. Monaco et al., "Influence of leptin and adiponectin on prostate cancer," Archivos Españoles de Urología, vol. 62, pp. 103-108, 2009.

[47] E. K. Wei, E. Giovannucci, C. S. Fuchs, W. C. Willett, and C. S. Mantzoros, "Low plasma adiponectin levels and risk of colorectal cancer in men: a prospective study," Journal of the National Cancer Institute, vol. 97, no. 22, pp. 1688-1694, 2005.

[48] A. Lukanova, S. Söderberg, R. Kaaks, E. Jellum, and P. Stattin, "Serum adiponectin is not associated with risk of colorectal cancer," Cancer Epidemiology Biomarkers and Prevention, vol. 15, no. 2, pp. 401-402, 2006.
[49] I. Wolf, S. Sadetzki, H. Kanely et al., "Adiponectin, ghrelin, and leptin in cancer cachexia in breast and colon cancer patients," Cancer, vol. 106, no. 4, pp. 966-973, 2006.

[50] L. Liu, R. Zhong, S. Wei et al., "Interactions between genetic variants in the adiponectin, adiponectin receptor 1 and environmental factors on the risk of colorectal cancer," PLoS ONE, vol. 6, Article ID e27301, 2011.

[51] L. G. Carvajal-Carmona, S. Spain, D. Kerr, R. Houlston, J. B. Cazier, and I. Tomlinson, "Common variation at the adiponectin locus is not associated with colorectal cancer risk in the UK," Human Molecular Genetics, vol. 18, no. 10, pp. 1889-1892, 2009.

[52] M. Dalamaga, I. Migdalis, J. L. Fargnoli et al., "Pancreatic cancer expresses adiponectin receptors and is associated with hypoleptinemia and hyperadiponectinemia: a case-control study," Cancer Causes and Control, vol. 20, no. 5, pp. 625-633, 2009.

[53] M. C. Chang, Y. T. Chang, T. C. Su et al., "Adiponectin as a potential differential marker to distinguish pancreatic cancer and chronic pancreatitis," Pancreas, vol. 35, no. 1, pp. 16-21, 2007.

[54] C. Weyer, T. Funahashi, S. Tanaka et al., "Hypoadiponectinemia in obesity and type 2 diabetes: close association with insulin resistance and hyperinsulinemia," Journal of Clinical Endocrinology and Metabolism, vol. 86, no. 5, pp. 1930-1935, 2001.

[55] R. E. Bachelder, M. A. Wendt, and A. M. Mercurio, "Vascular endothelial growth factor promotes breast carcinoma invasion in an autocrine manner by regulating the chemokine receptor CXCR4," Cancer Research, vol. 62, no. 24, pp. 7203-7206, 2002.

[56] E. Mueller, P. Sarraf, P. Tontonoz et al., "Terminal differentiation of human breast cancer through PPAR $\gamma$," Molecular Cell, vol. 1, no. 3, pp. 465-470, 1998.

[57] Y. Miyazaki, A. Mahankali, E. Wajcberg, M. Bajaj, L. J. Mandarino, and R. A. DeFronzo, "Effect of pioglitazone on circulating adipocytokine levels and insulin sensitivity in type 2 diabetic patients," Journal of Clinical Endocrinology and Metabolism, vol. 89, no. 9, pp. 4312-4319, 2004.

[58] F. Jaleel, A. Jaleel, J. Aftab, and M. A. Rahman, "Relationship between adiponectin, glycemic control and blood lipids in diabetic type 2 postmenopausal women with and without complication of ischemic heart disease," Clinica Chimica Acta, vol. 370, no. 1-2, pp. 76-81, 2006.

[59] S. E. Hankinson, W. C. Willett, J. E. Manson et al., "Alcohol, height, and adiposity in relation to estrogen and prolactin levels in postmenopausal women," Journal of the National Cancer Institute, vol. 87, no. 17, pp. 1297-1302, 1995.

[60] M. N. Dieudonne, M. Bussiere, E. Dos Santos, M. C. Leneveu, Y. Giudicelli, and R. Pecquery, "Adiponectin mediates antiproliferative and apoptotic responses in human MCF7 breast cancer cells," Biochemical and Biophysical Research Communications, vol. 345, no. 1, pp. 271-279, 2006.

[61] D. Barb, A. Neuwirth, C. S. Mantzoros, and S. P. Balk, "Adiponectin signals in prostate cancer cells through Akt to activate the mammalian target of rapamycin pathway," Endocrine-Related Cancer, vol. 14, no. 4, pp. 995-1005, 2007.

[62] Y. J. Jeong, J. G. Bong, S. H. Park, J. H. Choi, and H. K. $\mathrm{Oh}$, "Expression of leptin, leptin receptor, adiponectin, and adiponectin receptor in ductal carcinoma in situ and invasive breast cancer," Journal of Breast Cancer, vol. 14, no. 2, pp. 96$103,2011$. 
[63] X. Xiang, A. K. Saha, R. Wen, N. B. Ruderman, and Z. Luo, "AMP-activated protein kinase activators can inhibit the growth of prostate cancer cells by multiple mechanisms," Biochemical and Biophysical Research Communications, vol. 321, no. 1, pp. 161-167, 2004.

[64] N. Yamaguchi, J. G. M. Argueta, Y. Masuhiro et al., "Adiponectin inhibits Toll-like receptor family-induced signaling," FEBS Letters, vol. 579, no. 30, pp. 6821-6826, 2005.

[65] T. Fujisawa, H. Endo, A. Tomimoto et al., "Adiponectin suppresses colorectal carcinogenesis under the high-fat diet condition," Gut, vol. 57, no. 11, pp. 1531-1538, 2008.

[66] T. Kadowaki, T. Yamauchi, N. Kubota, K. Hara, K. Ueki, and $\mathrm{K}$. Tobe, "Adiponectin and adiponectin receptors in insulin resistance, diabetes, and the metabolic syndrome," Journal of Clinical Investigation, vol. 116, no. 7, pp. 1784-1792, 2006.

[67] R. Tsukinoki, K. Morimoto, and K. Nakayama, "Association between lifestyle factors and plasma adiponectin levels in Japanese men," Lipids in Health and Disease, vol. 4, article 27, 2005.

[68] J. L. Fargnoli, T. T. Fung, D. M. Olenczuk, J. P. Chamberland, F. B. $\mathrm{Hu}$, and C. S. Mantzoros, "Adherence to healthy eating patterns is associated with higher circulating total and high-molecular-weight adiponectin and lower resistin concentrations in women from the Nurses' Health Study," American Journal of Clinical Nutrition, vol. 88, no. 5, pp. 12131224, 2008.

[69] Y. Nakamura, H. Ueshima, N. Okuda et al., "Relation of dietary and other lifestyle traits to difference in serum adiponectin concentration of Japanese in Japan and Hawaii: the INTERLIPID Study," American Journal of Clinical Nutrition, vol. 88, no. 2, pp. 424-430, 2008.

[70] C. S. Mantzoros, C. J. Williams, J. E. Manson, J. B. Meigs, and F. B. $\mathrm{Hu}$, "Adherence to the Mediterranean dietary pattern is positively associated with plasma adiponectin concentrations in diabetic women," American Journal of Clinical Nutrition, vol. 84, no. 2, pp. 328-335, 2006.

[71] M. H. Rokling-Andersen, J. E. Reseland, M. B. Veierød et al., "Effects of long-term exercise and diet intervention on plasma adipokine concentrations," American Journal of Clinical Nutrition, vol. 86, no. 5, pp. 1293-1301, 2007.

[72] Z. Kovacova, M. Vitkova, M. Kovacikova et al., "Secretion of adiponectin multimeric complexes from adipose tissue explants is not modified by very low calorie diet," European Journal of Endocrinology, vol. 160, no. 4, pp. 585-592, 2009.

[73] K. Shinmura, K. Tamaki, K. Saito, Y. Nakano, T. Tobe, and R. Bolli, "Cardioprotective effects of short-term caloric restriction are mediated by adiponectin via activation of AMPactivated protein kinase," Circulation, vol. 116, no. 24, pp. 2809-2817, 2007. 


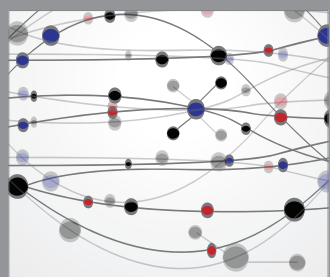

The Scientific World Journal
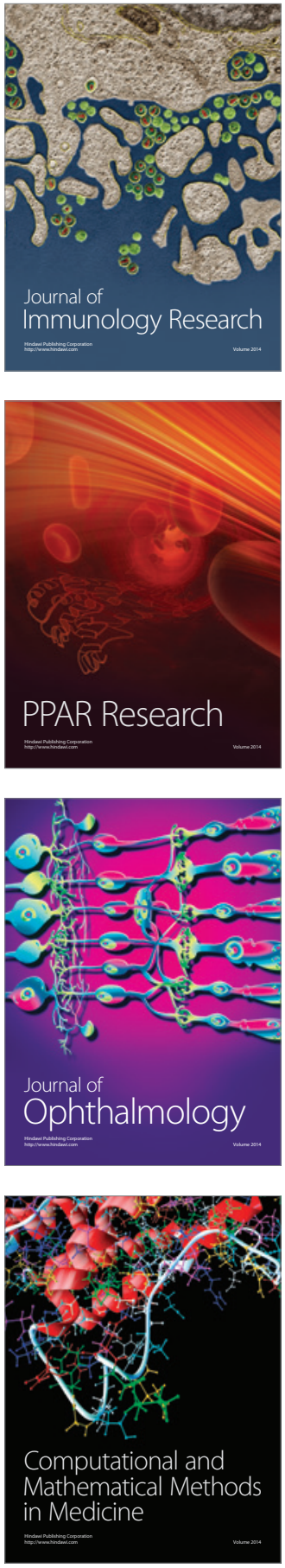

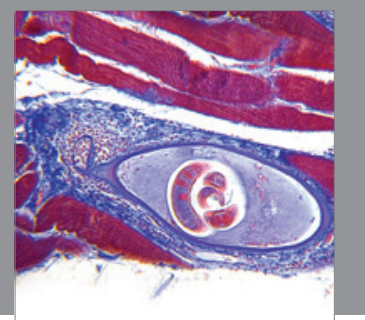

Gastroenterology

Research and Practice
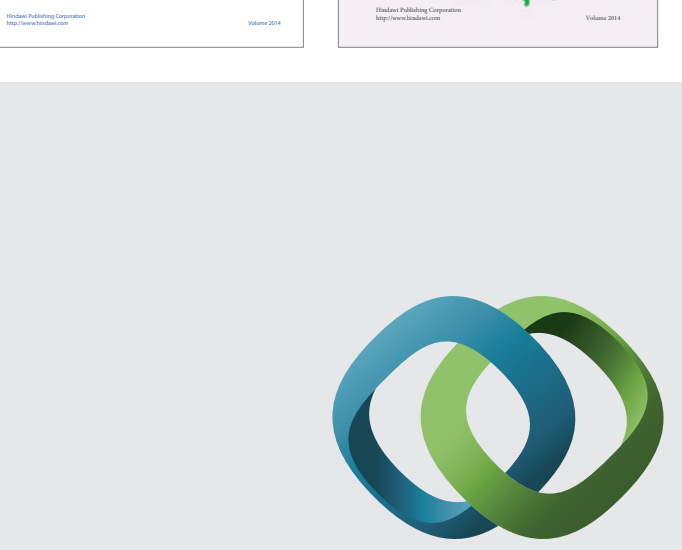

\section{Hindawi}

Submit your manuscripts at

http://www.hindawi.com
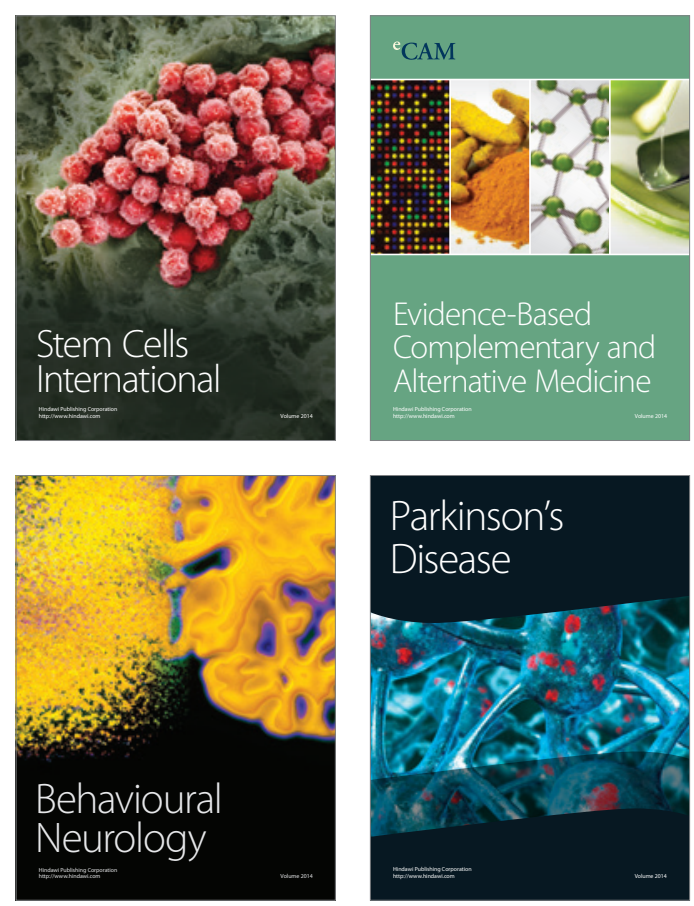

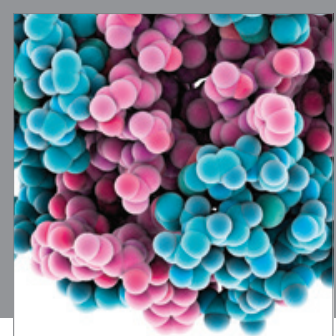

Journal of
Diabetes Research

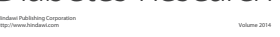

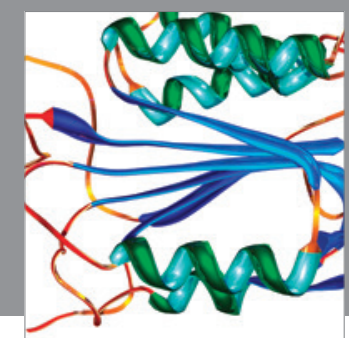

Disease Markers
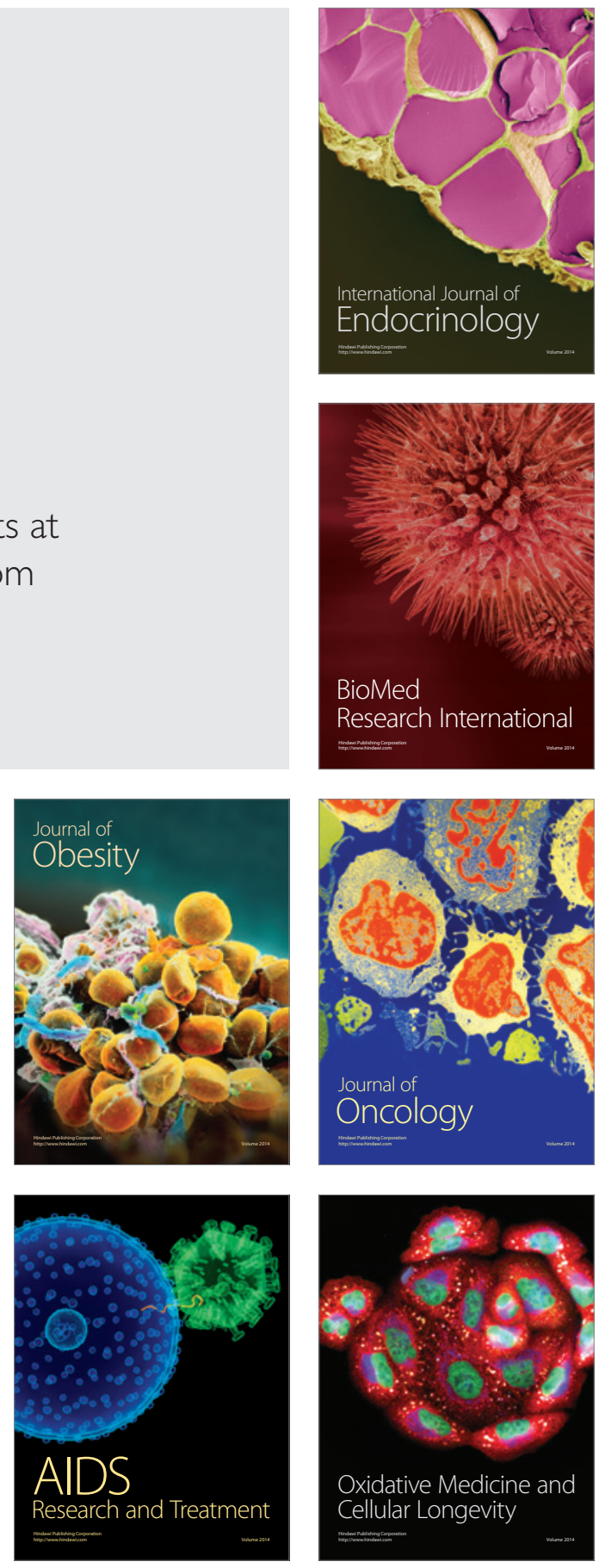